\title{
Cooperative learning and learning of the subject of language and literature in third year unified general baccalaureate students
}

Aprendizaje cooperativo y aprendizaje de la asignatura de lenguaje y literatura en estudiantes tercer año bachillerato general unificado

Aprendizagem cooperativa e aprendizagem da disciplina de língua e literatura em estudantes do terceiro ano do bacharelato geral unificadoThe basic training

\section{Esperanza Murillo García}

Master in Education, Universidad Estatal de Guayaquil, Guayaquil, Ecuador, https://orcid.org/0000-0001-8945-8998

\section{Abelardo Rodolfo Campana Concha}

D. in Education, Universidad Nacional Mayor de San Marcos, Lima - Peru, https://orcid.org/0000-0002-1098-9508.

\section{Received March 2021 - Accepted July 2021 \\ Revista Iberoamericana de la Educación \\ Vol - 5 No. 1, January - March 2022 \\ e-ISSN: 2737-632x}

Pgs 1-12

\section{Abstract:}

To know the influence of cooperative learning and learning the subject of language and literature, corresponds to the pre-experimental study, pre- and post-test instruments were applied, the sample consisted of 27 students, the data were processed by the SPSS statistic, pretest resulted with average 5.44 points, the average difference of the post-test with 8.33 points, showing an increase of 2.89 points, likewise occurs with the specific hypotheses, cooperative learning improved the learning of language and literature, showing improvements as a result of the strategy used.

Keywords: cooperative learning, language, literature.

Resumen: Conocer la influencia del aprendizaje cooperativo y aprendizaje de la asignatura de lenguaje y literatura, corresponde al estudio pre 
experimental, se aplicó instrumentos de pre y pos test, la muestra consistió 27 estudiantes, los datos fueron procesados por el estadístico SPSS, pretest resultó con promedio 5,44 puntos, la diferencia medias del postest con 8,33 puntos, evidenciando incremento de 2,89 puntos, igualmente ocurre con las hipótesis específicas, el aprendizaje cooperativo mejoró el aprendizaje del lenguaje y literatura, mostrando mejoras producto de la estrategia empleada. Palabras clave: aprendizaje cooperativo, lenguaje, literatura.

Resumo: Para conhecer a influência da aprendizagem cooperativa e da aprendizagem da disciplina de língua e literatura, corresponde ao estudo préexperimental, foram aplicados instrumentos pré e pós-teste, a amostra consistiu em 27 estudantes, os dados foram processados pela estatística do SPSS, o pré-teste resultou com uma média de 5,44 pontos, a diferença média do pós-teste com 8,33 pontos, mostrando um aumento de 2,89 pontos, também ocorre com as hipóteses específicas, a aprendizagem cooperativa melhorou a aprendizagem de língua e literatura, mostrando melhorias produto da estratégia empregada.

Palavras-chave: aprendizagem cooperativa, língua, literatura.

\section{INTRODUCTION}

The present study was conducted with the purpose of verifying how high school students use collaborative learning during their studies to improve their professional competencies.

(LOEI, 2011), the unified general baccalaureate mentions:

"It comprises three years of compulsory education following General Basic Education. Its purpose is to provide people with a general education and an interdisciplinary preparation that guides them in the 
development of life projects and allows them to integrate into society as responsible, critical and caring human beings" (p.23).

In addition, there are two options: a baccalaureate in science and a technical baccalaureate, the former trains students in scientific-humanistic areas, the latter focuses on technical, craft, sports or artistic areas.

According to the curriculum of the Ministry of Education of Ecuador (Minedu, 2016) the subject of Language and Literature fosters "in the student procedures and attitudes related to respect for themselves and others involved in the communicative process; the responsibility to assume one's own discourses, and the necessary academic honesty when generating them" (p.42).

However, we have evidenced that traditional teaching is still predominant, without guaranteeing student learning, only a few teachers take cooperative learning as an option, thus the need to promote it in order for students to improve their grades.

There are precedents, such as those of Martín (2015) who demonstrated the need to promote collaborative groups among teachers to contrast ideas, knowledge and conclusions, in order to train and transform teaching from daily practice. For his part, García (2015) considers that as students act with this methodology, in virtual groups they achieve good learning.

Therefore, the objective of this study is to analyze the influence between the use of cooperative learning and language and communication learning in third year students of the unified general high school in Guayaquil - Ecuador, 2020. Johnson, Johnson and Holubec (1999) mention: "cooperative learning is a methodological strategy that consists of the work done by a group of students in order to achieve common goals. In cooperation, individuals carry out joint 
activities to achieve results that are beneficial not only for themselves but for all members of the group".

Pliego (2011) defines "cooperative learning as a broad and heterogeneous set of structured instructional methods in which students work together, in groups or teams, helping each other in generally academic tasks".

Mayordomo and Onrubia (2015) explain that students have better understanding when the contents have a link with their previous ideas and representations, being able to control their own learning, this implication allows interaction with other people to contrast their ideas, indicating that collaborative learning fits perfectly with "instructional and educational proposals that try to overcome the limitations of a traditional conception of teaching, betting on the design of new and more powerful teaching and learning environments".

Feldman (2005) defines learning as "a process of relatively permanent change in a person's behavior generated by experience".

Pérez (2000, p.73) states that learning is "any modification of the organism that originates a new pattern of thought and/or behavior". Pérez (2015, p.72) affirms that learning "is the activity of the person that aims at the knowledge of the truth. In it participates the self in its integrity, but in a special way the faculties related to knowledge, such as the senses and the intellect, together with the will".

Anderson (2001) considers that learning is a mechanism by which organisms can adapt to a changing environment.

Barriga (2015) mentions: "it is a type of border, it occurs in earlier stages of speech development, the individual reaches the basic knowledge of the system, linguistic competence, and the final stages, restructures what has been learned, linguistic knowledge is adapted to the social system, through communicative competence". 
Ortega (2018) states, "at the end of the preschool stage they develop fundamental linguistic skills, based on obtaining all the phonemes of the language, also writing skills and semantic acquisitions, showing fluency to communicate orally".

Franja (2015) mentions that language is given through the cognitivist model, within which the relevance of the environment stands out as well as the inner capacity of the individual to be able to form a bond with the surrounding environment, thereby emphasizing that a mutual relationship must be established.

\section{MATERIALS AND METHODS}

This pre-experimental applied research was applied to a single group, and the following aspects were considered:

Type of question : Applied

Hypothesis testing : Cause - effect

Measurement variables : Quantitative

Number of variable : Bivariate

Environment : Field

Data source : Primary

Application : Longitudinal

Design : Pre experimental

For statistical purposes and to test the hypotheses, the SPSS 21 program was used to process the data found in the instruments applied and to demonstrate the hypotheses proposed. The following graph explains the pre-experimental design:

$\mathrm{GE}=\mathrm{O} 1$

GE: Sample or working group

O1: observation 1 
O2: observation 2

$\mathrm{X}$ : Training

Reliability of the instruments: they were subjected to Cronbach's Alpha, result.

Table 1: Reliability

\begin{tabular}{rrr}
\hline Cronbach's alpha & N of elements & \\
, 675 & & 4 \\
\hline
\end{tabular}

The reliability of the instrument was applied to the dependent: learning the subject of language and literature, according to Cronbach's alpha was 0.675, representing $67.5 \%$, representing a good tendency for its application.

\section{RESULTS}

The collaborative teaching strategy was applied in the present study for a period of 4 months, so that students could improve their language and literature skills.

During the process of application of the mentioned strategy, the learning outcome on the subject shown by the sample has been positively evidenced. After the process was completed, it was possible to achieve the proposed objective presented below:

The use of cooperative learning increases the learning of language and communication in students of third year general unified high school Guayaquil - Ecuador, 2020.

Table 1. Mean difference: dependent variable

\begin{tabular}{lrrr}
$\begin{array}{l}\text { Language and } \\
\text { Literature }\end{array}$ & $\mathrm{N}$ & Media & \multicolumn{1}{c}{$\begin{array}{c}\text { Standard } \\
\text { deviation. }\end{array}$} \\
Pre test & 27 & 5,44 &, 641 \\
Posttest & 27 & 8,33 &, 814
\end{tabular}

Source: Esperanza Murillo (2020) 
The pre-test averages reached an average of 5.44, while the post-test score was 8.33, which proves the effectiveness of collaborative learning in the subject of language and literature.

Cooperative learning enhances the learning of 19th century poetry.

Table 2. Mean between pre- and post-test dimension 1

\begin{tabular}{|l|r|r|r|r|}
$\begin{array}{l}\text { Nineteenth } \\
\text { Century Poetry }\end{array}$ & N & Media & Deviation. & \multicolumn{1}{c|}{$\begin{array}{c}\text { Mean } \\
\text { standard } \\
\text { error }\end{array}$} \\
\hline Pre test & 27 & 5,37 &, 688 &, 132 \\
\hline Post test & 27 & 7,74 &, 712 &, 137 \\
\hline
\end{tabular}

A mean difference of 2.37 was found between the entry and exit tests.

The pretest mean reached an average of 5.37, then when applied in the posttest it was 8.33, thus proving the effectiveness of collaborative learning in the topics of 19th century Poetry.

Cooperative learning enhances the learning of 19th century Ecuadorian narrative.

The pretest mean reached an average of 5.70, then when applied in the posttest it was 8.70, thus proving the effectiveness of collaborative learning in the topics of the Ecuadorian narrative of the nineteenth century.

Cooperative learning has an impact on the learning of 19th and 20th century Ecuadorian literature.

The pretest mean reached an average of 5.37, then when applied in the posttest it was 7.96, thus proving the effectiveness of collaborative learning in the subjects of 19th and 20th century Ecuadorian literature.

Cooperative learning helps the learning of the poets of the second half of the 20th century. 
In the pretest the students achieved an average of 5.37, then when applied in the posttest it was 8.22, thus proving the effectiveness of collaborative learning in the topics of Poets of the second half of the twentieth century. Cooperative learning increases the learning of the narrator of the 20th century. In the pretest the students achieved an average of 5.59, then when applying the posttest evaluation, the result was 8.56 , thus proving the effectiveness of collaborative learning in the topics of Narrators of the 20th century. Cooperative learning helps the learning of literature of the late twentieth century and early twenty-first century.

The pretest mean reached an average of 5.59, then when applied in the posttest it was 8.56, thus proving the effectiveness of collaborative learning in the subjects of Literature of the late twentieth century and early twenty-first century.

The research consisted of answering the research objectives. In the general hypothesis, an average of 5.44 was obtained with respect to the pretest mean, while in the posttest an average of 8.33 was reached, that is, with the application of cooperative learning, the students achieved an increase of 2.89 in their grades that represent the learning of the subject of language and literature.

Responding to the approach of the first specific hypothesis, the pretest mean obtained an average of 5.37, on the other hand the posttest achieved a score of 7.74, confirming the benefit of applying cooperative learning with this increase (2.37) of their learning with respect to the poetry of the nineteenth century.

The second specific hypothesis, the pretest mean obtained an average of 5.70, then in the posttest a score of 8.70, with this increase of 3.00 the positive actions that cooperative learning generates in the themes of the Ecuadorian narrative of the XIX century are proven. 
In $\mathrm{H} 3$, the pretest results reached an average of 5.37, then in the posttest evaluations the students achieved an average score of 7.96, evidencing an increase of 2.59 in the grades referring to Ecuadorian Literature XIX and XX century, as a positive consequence of applying cooperative learning.

In the approach of $\mathrm{H} 4$, the results of the pretest the students reached an average of 5.37, however these grades increased in the posttest whose average was 8.22 , that is a difference of 2.85 , thus proving the effectiveness of cooperative learning on the topic of Poets of the second half of the twentieth century.

In response to the approach of the fifth specific hypothesis, the pretest mean obtained an average of 5.59, on the other hand the posttest achieved a score of 8.56, confirming the benefit of applying cooperative learning with this increase (2.97) of their learning with respect to the 20th century Narrators.

The sixth specific hypothesis, the pretest mean obtained an average of 5.59, then in the posttest a score of 8.56 , with this increase of 2.97 proves the positive actions that cooperative learning generates in the subjects of Literature of the late twentieth century and early twenty-first century. Contrasting these results with those of Alvarez (2015) evidenced the benefits of cooperative learning, alerting more interaction among students, however they consider they should be motivated by the teacher, although it does not explain if it has a positive link in their grades, as if evidenced in our study, it has the similarity of generating improvements in different formative aspects. However, the results of Pinedo (2017) confirm the opposite, since according to his statistical results cooperative learning are not related per se, however, it is necessary to perform a cooperative approach and methodology to analyze the changes made in students. 


\section{CONCLUSIONS}

Cooperative learning helps to improve grades in the subject of language and literature, because before its application most of the students were failing, however, considering this methodology they got very good grades. It is positive to apply cooperative methodologies in high school students, because they were able to increase their average in 2.37 points regarding Poetry of the XIX century, going from failing (pretest) to good grades (posttest).

The students' knowledge about the Ecuadorian Narrative of the XIX century increases with the application of cooperative learning, since the students in the pretest and posttest obtained mostly failing and very good grades, respectively, alerting its effectiveness.

High school students are able to improve their knowledge of 19th and 20th century Ecuadorian Literature through a cooperative methodology, because their results in pretest evaluations reached mostly failing grades, while in their posttest tests, good, proving this increase in 2.59 points.

Cooperative learning allowed students to improve their averages in reference to the theme of Poets of the second half of the twentieth century, going from failing grades (pretest) to good grades (posttest), for the most part, demonstrating its effectiveness for its application in the baccalaureate.

It is effective that cooperative learning is applied in high school students, since it allows them to improve their grades in the subject of Narrators of the 20th century, who went from an average of 5.59 (pretest) to 8.56 (posttest), most of them with very good grades.

Learning helps to increase the knowledge of Literature of the late 20th and early 21 st century in high school students, who at first stood out for their failing grades, but later with the post-test and the appropriate methodology, most of them achieved very good averages. 


\section{REFERENCES}

Alvarez, V. (2015) ICT-mediated cooperative learning in university teaching: an approach to the perceptions and experiences of teachers and students at the Autonomous University of Chihuahua [Doctoral Thesis, University of Salamanca]. Available at: https:/gredos.usal.es/bitstream/handle/10366/127968/DDOMI_Alva rezOlivasV_MetodosAudiovisualesPedagogia.pdf?sequence=1\&isAl lowed $=\mathrm{y}$

Anderson, J. (2001). Learning and memory. A comprehensive approach. Mexico: Mc Graw Hill.

Barriga, R. (2015). Study on children's speech in the school years. Editorial del Colegio de México.

Feldman, J. (2002). Self-esteem: How to develop it? Narcea S.A. de Ediciones.

García, C. (2015). Cooperative learning in virtual groups (relationships between conditions, processes and learning outcomes of higher education students in virtual environments [Doctoral Thesis, Open University of Catalonia. Available at: https://www.tesisenred.net/bitstream/handle/10803/307052/Tesis\%2 0Consuelo\%20Garcia $\% 20$ Tamarit.pdf? sequence=1\&isAllowed=y

Johnson, D., Johnson, R., \& Holubec, E. (1999). Cooperative learning in the classroom. Editorial Paidós.

Law No. 417 of 2011. Organic Law on Comprehensive Education. March 31, 2011.

Martín, G. (2015). Use of cooperative learning for the transformation of student learning and continuing education of teachers in a rural grouped center [Doctoral Thesis, University of Valladolid]. Available at:

http://uvadoc.uva.es/bitstream/handle/10324/7536/TESIS604141209. pdf? sequence $=1 \&$ isAllowed $=y$

Mayordomo, R. and Onrubia, J. (2015). El aprendizaje cooperativo. Editorial $\mathrm{AOC}$

Ministry of Education of Ecuador (2016). Curriculum for $E G B$ and $B G U$. Lengua y Literatura. Available at: https://educacion.gob.ec/wpcontent/uploads/downloads/2016/03/LENGUA.pdf 
Ortega, R. (2018). Levels of oral language development in 5-year-old children of the network $N^{\circ} 1$ of ventanilla - Callao [Tesis Magisterial, Universidad San Ignacio de Loyola].

Pérez, P. (2015). An educational theory. Theories of learning. University of Piura, Nuestra Señora del Pilar, Vida y Familia.

Pinedo, M. (2017). Cooperative learning and academic performance in university students of the faculty of administration of the Universidad Nacional Federico Villareal, 2017 [Tesis Magisterial, Universidad César Vallejo].

Pliego, N. (2011). Cooperative learning and its advantages in Intercultural Education. Hekademos Digital Educational Journal, 4 (8). Available at: https://dialnet.unirioja.es/descarga/articulo/3746890.pdf 